\title{
Linkage Strategies, Resource Conditions and University Performance
}

\author{
Orucho Michael Ngala ${ }^{1} \&$ Zachary Bolo Awino ${ }^{2}$ \\ ${ }^{1}$ School of Business and Economics, The Co-operative University of Kenya, Nairobi, Kenya \\ ${ }^{2}$ School of Business, University of Nairobi, Nairobi, Kenya \\ Correspondence: Orucho Michael Ngala, School of Business and Economics, The Co-operative University of \\ Kenya, Nairobi, Kenya, P.O BOX 53535-00200, Nairobi, Kenya. Tel: 254-721-670-417. E-mail: \\ oruchomiko@gmail.com
}

Received: June 20, 2017

Accepted: July 18, 2017

Online Published: August 12, 2017

doi:10.5539/ijbm.v12n9p153

URL: https://doi.org/10.5539/ijbm.v12n9p153

\begin{abstract}
This study sought to contribute to knowledge by assessing the moderating effect of resource conditions on the relationship between linkage strategies and performance of universities in Kenya. Resource based view was used as the main theory anchoring the study. Cross-Sectional survey was adopted as the research design. The population of the study consists of sixty five (65) public and private universities incorporated in Kenya. Out of this, a sample of forty seven (47) universities which had undergone at least one graduation cycle was taken. Primary and secondary data was collected using semi-structured questionnaires and review of existing university documents and regulatory bodies' websites respectively. Correlation and regression analyses were carried out to analyse data and to test hypotheses. Although it was not possible to include all the determinants of institutional performance, balanced score card was appropriately used to represent financial and non-financial aspects that constitute performance indicators. It was established that resource conditions have enhancing moderating effect on the relationship between linkage strategies and university performance in Kenya. The significance of firm resources and linkage components in strategy formulation and implementation cannot be overlooked. The key recommendation that the study offers as insights to theory, university authorities and policy makers, is the need to consider firm resource conditions as critical determinants during strategy formulation and implementation process in order to enhance university performance. The main limitation of this study is that primary data was collected from only one respondent per university but common methods bias was mitigated through the use of additional secondary data to validate primary data.
\end{abstract}

Keywords: linkage, strategy, economic sector, resource conditions, university performance

\section{Introduction}

\subsection{Research Problem}

There have been attempts to examine the relationships among resource conditions, strategy, and performance. However, research examining that threefold relationship has not adequately addressed the issue of whether resource conditions are independently related to performance, moderators of the relationship or some combination of the two (Prescott, 1986). This study therefore attempted to fix this gap. The heightened debate on competitive forces attempt to explain why some firms perform better than others within the same industry. Resource based view emphasises the critical role of internal firm resources in determining firm performance. Careful choice of strategy and appropriate implementation, taking resource conditions into consideration, should contribute to enhanced organizational performance. Strategy is largely influenced by internal resource conditions of a firm. Internal conditions look inwardly towards the resources available to the firm. However, not all resources are of equal importance or possess the potential to be a source of sustainable competitive advantage (Wernerfelt, 1984). This argument implies that a firm may have many resources that can be strategically utilised to improve firm performance, but appropriate choice must be made to identify specific resources that can provide superior firm performance. Much attention has focused on the characteristics of advantage-creating resources which meet the conditions of value, inimitability, rareness and non-substitutability. In Kenya, the need to enhance linkages between universities and industry has often been cited in several Government Publications (Government of Kenya Development Plan 1994-1998; Report of the National Conference on Education, 2004; KESSP, 2005; Sessional Paper No.1 2005; Kenya Vision 2030, 2007). From the corporate sector, there are 
emerging strong calls for collaboration between the productive sector and higher learning institutions.

\subsection{Resource Based View and Resource Conditions}

Resource Based View attributes primary role of internal resource conditions to firm performance (Wernerfelt, 1984 and Collis and Montgomery, 1995). This view looks at a firm as a pool of both tangible and intangible resources embodied in skills and in the interactions between people and systems. Intangible resources are unique to each firm and, when a firm finds itself with different uses for its excess resources, it will often choose those combinations that are tied most closely with its previous activities in order to realize sustainable competitive advantage by creating value, rareness, non-substitutability and inimitability in the resource combinations. The question of value is intended to ascertain whether or not a particular resource of a firm is strategically relevant. If the firm receives a benefit that outweighs the carrying cost of a strategy, then it is concluded that the resource is valuable and is therefore a potential source of competitive advantage leading to better performance. According to Barney (1991), value is a resource advantage creating condition that enable a firm to employ a value-creating strategy, by either outperforming its competitors or reduce its own weaknesses hence appeal to its internal and external customers. The resources of an organization must be geared towards continuous improvement, superior quality and some level of prestige. Rareness seeks to establish whether a strategy creates a difference between a firm and its competitors, such that the firm realizes some advantage and superior performance from the difference. Rareness is therefore tied to the assumption of resource or strategy heterogeneity. A resource or strategy is considered rare if so few firms possess a similar resource or strategy that nearly perfect competition is not observed (Barney, 1991). Inimitability refers to inability of competitors in an industry to copy a firm's bundle of resources. A firm can expect to sustain its competitive advantage and superior performance if other firms face a cost disadvantage in trying to imitate its valuable and rare strategy or resource. Intangible resources are usually more difficult to imitate and therefore are more likely to be sources of sustained competitive advantage. Strategically combined resources are more difficult to imitate than a single one. According to Carter and Ruefli (2006), inimitability is perhaps the most important predictor of organizational performance as a firm can obtain superior returns only when other firms are unable to imitate its resources and capabilities, otherwise these resources and capabilities would be less rare or valuable, and substitutability would become irrelevant. For a firm to achieve non-substitutability condition there must not be strategically equivalent valuable resources that are themselves either not rare or imitable. If two resources can be utilized separately to implement the same strategy then they are strategically equivalent but are substitutable and therefore not sources of sustained competitive advantage (Barney, 1991; Collis and Montgomery, 1995).

\subsection{University and Economic Sector Linkage Strategies}

Studies exploring linkages between higher education and industry have shown that having a strong symbiotic relationship between the two would enable the synergies to be exploited. This implies that performance of a higher learning institution should be measured in terms of quality of linkage it has with the economic sector. The economic sector constitutes all the stakeholders who exert influence and with interest in the university education. It includes the business, agricultural and public sectors that consume university education by providing employment opportunities to university graduates. The economic sector continually demands for relevant and competitive human resources from higher learning institutions (Ginies and Mazurelle, 2010). According to Eshiwani (1999), a university can only remain relevant if it responds promptly to the changing technology and emerging industry demands, by formulating proper linkage strategies. Munyoki et al. (2011) noted that firms are reluctant to pay for new ideas, while universities tend to become too profit oriented as opposed to transferring the inventions to seek relationships with companies. The indicators of quality linkage strategies that foster relationships between economic sector and higher education were established by both Karanja (2011) and Chatterton and Goddard (2001) as curriculum orientation, enhanced industrial attachment, appropriate teaching and learning facilities and collaborative research. From the previous studies, curriculum orientation, industrial attachment focus, teaching and learning focus and collaborative research constitute key indicators of university-economic sector linkage strategies.

\subsection{University Performance}

Kaplan and Norton (2008) introduced balance scorecard which considers other non-financial measures of performance such as internal business process, learning and growth and customer perspective. Financial indicators used include net surplus and scholarship/grants awarded to learners. Net profit, also referred to as the bottom line, net income, or net earnings is a measure of the profitability of a venture after accounting for all costs. It is the money left over after paying all the expenses of an endeavor. Net profit is an indicator of appropriate financial health of an organization and its ability to expand and achieve more growth and stability. 
Grants and scholarships are the most desirable types of funding that learners can receive to pay for you're the cost of education, since they don't need to be repaid. Typically, most sponsors normally make payments directly to the institution where the learner is. This indicator reflects the stakeholder approval of a given university. Universities perceived to be of low quality would not benefit from such grants and scholarship awards for groups of students. According to Kaplan and Norton (2008), the business process perspective refers to internal business processes. Metrics based on this perspective allow the managers to know how well their business is running, and whether its products and services conform to customer requirements thus fulfilling organizational mission. Collaborative activities, stakeholder conferences, industry visits and invited guest speakers were used as internal business process perspective. As performance indicators they reflect the coordination and impact a university makes at corporate level and with the economic sector. As part of learning process, these activities enable learners to get insight regarding the internal working environment of a company and how a company functions, as well as useful information related to the practical aspects of the educational course which cannot be visualized in a normal lecture in a classroom set up. Learning and growth perspective indicators used include teacher to student and supervisor to student ratios. Teacher to student ratio is the number of teachers divided by the number of learners in a given institution. Supervisor to student ratio is the number of research supervisors divided by the number of students undertaking research in a given institution. Smaller number of students per every teacher or research supervisor is widely believed to benefit all learners because of individual attention from teachers or research supervisor. Low-attaining learners are seen to benefit more where the content is complex. Learners in large groups drift off task because of too much instruction from the teacher or research supervisor to the whole group instead of individual attention, and low-attaining students are most affected. Reasonable ratios tend to reduce the learners achievement gap. As performance indicators, the ratios reflect the level of compliance to quality academic standards. According to Spyros and Vicki (2009), one teacher should ideally teach not more than forty students in a class and that every research supervisor should be assigned at most five research students. According to Aguillo et al. (2006), the ranking web or webometrics is the largest academic ranking of higher education institutions. The ranking was therefore used as an indicator of customer perspective to reflect the level of educational value and reputation that stakeholders attach to a given university. Thus, the universities consistently ranked at the top were considered to reflect greater stakeholder approval. The recent popularity of world university rankings amplifies the higher education reputation race. The global university webomatrics ranking provides extra stimuli for both policy-makers, and higher education institutions to try to conquer higher positions at the global ladders of institutional reputation.

\subsection{Hypotheses of the Study}

The following hypotheses are derived from the literature debate:

Hypothesis 1: There is significant relationship between linkage strategies and organisational performance.

Hypothesis 2: There is significant relationship between resource conditions and organisational performance.

Hypothesis 3: There is significant moderating effect of resource conditions on the relationship between linkage strategies and organisational performance.

\subsection{Conceptual Framework}

An integrated framework to respond to the knowledge gaps identified in the literature review in this study has been designed with two components. Linkage strategies constitute independent variables, industry forces constitute moderating variables and organisational performance constitutes dependent variable.The study determined the direct relationship between linkage strategies and organisational performance.

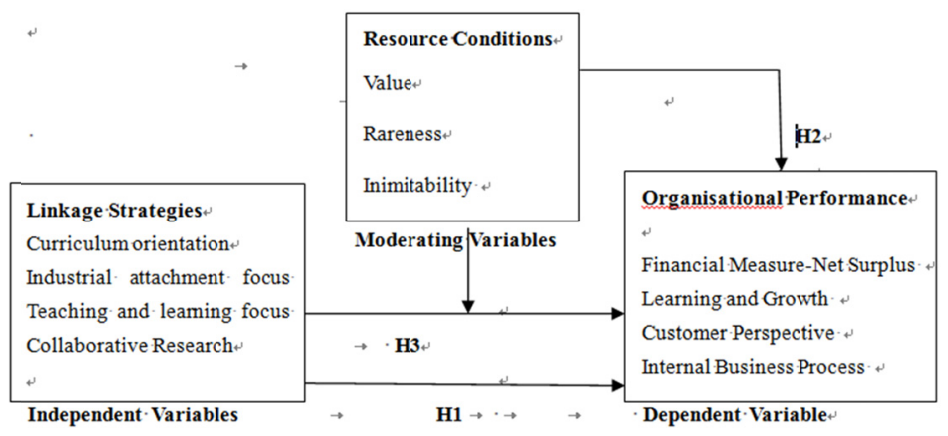

Figure 1. Conceptual Model 


\section{Method}

\subsection{Participant Characteristics}

Apart from two financial aspects in section D, the rest of the questions concentrated on academic strategies. A total of forty seven (47) questionnaires were distributed, one in each of the forty seven (47) universities. While in some universities the deputy vice chancellor (DVC) academic affairs completed the questionnaire, most of the universities had the registrar academic affairs in charge of academic affairs and therefore completed the questionnaire. Respondents complemented section D of the questionnaires on net surplus and scholarship awards in consultation with their respective finance officers.

\subsection{Sampling Procedures}

Population stands for the entire collection of objects we want to study. If it is small enough, it can be studied in its entirety. According to Herman and Renz (1998), all items in a population constitute population while sampling is a method of studying from a few selected and representative items, instead of the entire big number of units in order to infer and generalize the population characteristics. As at the time of this study, there were a total of sixty five (65) universities operating in Kenya (Commission for University Education, 2013). Population of this study is thus constituted of 65 public and private universities incorporated in Kenya. However, only forty seven (47) universities which had undergone at least one (1) graduation cycle were sampled.

\subsubsection{Sample Size, Power, and Precision}

Thus a sample of 47 (72\%) universities was used in the study. According to Kothari (2004), a population sample constituting $10 \%$ and above is appropriate if the researcher is dealing with a homogenous population.

The data collection instrument was tested using expert judgement to confirm whether the theoretical dimensions emerged as conceptualized. The test relied on expert assessment of senior researchers and professionals. The study espoused the views of Dess et al. (1993) that, "when a construct or a set of dimensions exhibits a strong content validity, there is a tendency among researchers to accept them without rigorous testing of other components of validity such as convergent, discriminant or nomological validity" (p. 785). Reliability test for equivalence was undertaken through questionnaire pretesting by a pilot study of 20 randomly selected universities within the population. Dillman (2000) suggested that a pilot study is conducted to ensure clarity and proper interpretation of the questionnaire by the expected respondents. The feedback obtained helped to revise the scales, address the structure of the questions and the overall design of the questionnaire. As a result, some questions which were ambiguous were reconstructed and duplicated ones were deleted from the original questionnaire before administering the final one to all study respondents. Reliability test for internal consistency of the instrument was measured through Cronbach's alpha coefficient. Kline (1999) noted that acceptable value for Cronbach's alpha is 0.7 or more. According to Nachmias and Nachmias (2004), Cronbach's alpha coefficient is used to measure the reliability of internal consistency of a research in which a Likert type scale with multiple answers is used to collect data. Cronbach's alpha coefficient was computed from the composite indices of all the independent, moderating and dependent variables used in the study. Each index was computed as the arithmetic mean obtained from all the respondents answering each part of the questionnaire. The alpha scores for each variable were within the valid ranges.

\subsubsection{Measures and Covariates}

Both primary and secondary data were collected and used in the study. Primary data were obtained from responses to the questionnaire. The respondents completed semi-structured by themselves over an agreed and specified period, after which the researcher picked the feedback. In other cases where appropriate, the respondents completed the questionnaires in the presence of the researcher. Secondary data comprised data sets that were already available in universities and other places previously collected for other use other than the current study. Secondary data was mainly obtained from Global University webometrics ranking's web-site. Some respondents also tabulated data on performance from existing records. According to Bryman and Bell (2007), a Likert scale is a psychometric scale commonly involved in research that employs questionnaires under different scales, and that as opposed to larger scales, five-point scales are better suited when rating against one attribute such as familiarity of issues being investigated among respondents. The items were developed from a wide review of literature from which ideas were moderated to suit the concepts and context of this study. The questionnaire for this study was thus designed on a five point Likert-type scale. The responses were $1=$ strongly disagree, $2=$ disagree, $3=$ not sure, $4=$ agree and $5=$ strongly agree.

\subsubsection{Research Design}

This study adopted descriptive cross-sectional survey. The cross-sectional approach involved collecting and 
comparing data from the phenomena as at the time of study. The design employ either qualitative or quantitative data. The combination of qualitative and quantitative data enabled adequate explanation of the variables and predictions in their behavior without resorting into inquiries of the temporal effect. The chosen design was deemed appropriate for this study because it improved accuracy in generalizing findings since it involved detailed study of a unit. The design enhanced uniform data collection and comparison across respondents. The design was used to identify patterns of convergence that had developed to corroborate the overall interpretation of the relationships and interdependences among the variables.

\section{Results}

The primary and secondary data gathered were cleaned, coded, sorted, analyzed, interpreted and presented in different tables.

3.1 Correlation and Regression Analysis between Linkage Strategies and University Performance

Table 1. Correlations between linkage strategies and university performance

\begin{tabular}{lll}
\hline & & University Performance \\
\hline University Performance & Pearson Correlation & 1 \\
& Sig. (2-tailed) & \\
Curriculum Orientation & $\mathrm{N}$ & 44 \\
& Pearson Correlation & $.895^{* *}$ \\
& Sig. (2-tailed) & .000 \\
Industrial Attachment Focus & $\mathrm{N}$ & 44 \\
& Pearson Correlation & $.868^{* *}$ \\
Teaching and Learning Focus & Sig. (2-tailed) & .000 \\
& $\mathrm{~N}$ & 44 \\
& Pearson Correlation & $.864^{* *}$ \\
& Sig. (2-tailed) & .000 \\
Collaborative Research & $\mathrm{N}$ & 44 \\
& Pearson Correlation & $.919^{* *}$ \\
& Sig. (2-tailed) & .000 \\
& $\mathrm{~N}$ & 44 \\
& Pearson Correlation & $.979^{* *}$ \\
& Sig. (2-tailed) & .000 \\
& $\mathrm{~N}$ & 44 \\
\hline
\end{tabular}

Source: Primary data, 2014

**. Correlation is significant at the 0.05 level (2-tailed).

Correlation analysis was done after aggregating the variables as composite indices. When Pearson's product moment correlation coefficient (r) was computed, it was established that there exists high positive correlation between linkage strategies and university performance since $r=0.979$, which is greater than 0.7 . The correlation is significant at $\mathrm{p}$ value $(0.000)<0.05$ as shown in Table 1. Correlation analysis between the indicators of linkage strategies and university performance shows that collaborative research has the highest positive correlation with university performance with Pearson's product moment correlation coefficient $(r)=0.919$, which is greater than 0.7 . This was followed by curriculum orientation, Industrial attachment focus and teaching and learning focus with $\mathrm{r}=0.895,0.868$ and 0.864 respectively. The correlation is significant at $\mathrm{p}$ value $(0.000)<$ 0.05 . 
Table 2. Regression Summary and ANOVA on Linkage Strategies and Performance

\begin{tabular}{|c|c|c|c|c|c|c|c|c|c|c|}
\hline \multirow[b]{2}{*}{ Regression } & \multicolumn{2}{|c|}{$\begin{array}{l}\text { Standardised } \\
\text { Coefficients }\end{array}$} & \multirow[t]{2}{*}{ Sig. } & \multirow{2}{*}{$\begin{array}{l}\mathrm{R} \\
.940^{\mathrm{a}}\end{array}$} & \multirow{2}{*}{$\begin{array}{l}\text { R Square } \\
.883\end{array}$} & \multirow{2}{*}{$\begin{array}{l}\mathrm{F} \\
73.531\end{array}$} & \multirow{2}{*}{$\frac{\mathrm{Df}}{4}$} & \multirow{2}{*}{$\begin{array}{l}\text { Sig. } \\
.000^{\mathrm{a}}\end{array}$} & \multicolumn{2}{|c|}{ Collinearity Statistics } \\
\hline & $\mathrm{B}$ & Std. Error & & & & & & & Tolerance & VIF \\
\hline Constant & .493 & .220 & .0312 & & & Residual & 39 & & & \\
\hline $\begin{array}{l}\text { Curriculum } \\
\text { Orientation }\end{array}$ & .041 & .177 & .0531 & & & & & & 0.078 & 10.12 \\
\hline $\begin{array}{l}\text { Industrial Attachment } \\
\text { Focus }\end{array}$ & .121 & .132 & .0512 & & & & & & 0.144 & 6.92 \\
\hline $\begin{array}{l}\text { Teaching and Learning } \\
\text { Focus }\end{array}$ & .125 & .138 & .0543 & & & & & & 0.181 & 5.51 \\
\hline $\begin{array}{l}\text { Collaborative } \\
\text { Research }\end{array}$ & .451 & .135 & .0411 & & & & & & 0.091 & 10.9 \\
\hline
\end{tabular}

Regression model is significant at the 0.05 level (2-tailed).

Source: Primary data, 2014.

Regression analysis was carried out to establish the equations for the models. To fix collinearity the stepwise method of model selection was used in order to include only the most useful variables in the models. Collinearity is indicated by tolerance close to zero (0) and variance inflation factor (VFI) greater than ten (10). Tolerance is the percentage of the variance in a given predictor that cannot be explained by the other predictors. A variance inflation factor greater than 10 is usually considered problematic. When each linkage strategy was regressed with university performance as shown in Table 2, collaborative research $(\mathrm{R})$ was found the most significant predictor of university performance $\left(\mathrm{Y}_{1}\right)$ with $\mathrm{p}$ value $(0.0411)<0.05$ followed by industrial attachment focus (I) with $\mathrm{p}$ value $(0.0512)$ and then curriculum orientation $(\mathrm{C})$ and teaching and learning focus $(\mathrm{T})$ respectively $(\mathrm{p}$ values $=$ 0.0531 and 0.543 respectively). The regression model relating each linkage strategy and university performance can be expressed as $\mathrm{Y}_{1}=0.49+0.04 \mathrm{C}+0.13 \mathrm{I}+0.12 \mathrm{~T}+0.45 \mathrm{R}$. The model implies that a unit percentage increase in curriculum orientation would cause $0.04 \%$ increase in university performance, a unit percentage increase in industrial attachment focus would cause $0.13 \%$ increase in university performance, a unit percentage increase in teaching and learning focus would cause $0.12 \%$ increase in university performance and that a unit percentage increase in collaborative research would cause $0.45 \%$ increase in university performance. Table 2 shows that $\mathrm{F}$ (4, $39)=73.531$ and $p$ value $<0.001$, tolerance values $>0$ and most VIF values $<10$, thus the regression model is a valid relationship between linkage strategies and university performance. Consequently the first research hypothesis was accepted as follows: Hypothesis 1: There is a significant relationship between linkage strategies and university performance.

\subsection{Correlation and Regression Analyses on Resource Conditions and Study Variables}

Table 3 shows high positive correlation between university resource conditions $\left(\mathrm{X}_{2}\right)$ and university performance (Y) with $\mathrm{r}=0.95>0.7$ and correlation being significant at $\mathrm{p}$ value $(0.000)<0.05$.

Table 3. Correlations between Study Variables

\begin{tabular}{llllll}
\hline & & $\mathrm{Y}$ & $\mathrm{X} 1$ & $\mathrm{X} 2$ & $\mathrm{X} 3$ \\
\hline $\mathrm{Y}$ & Pearson Correlation & 1 & $.979^{* *}$ & $.950^{* *}$ & $-.947^{* *}$ \\
& Sig. (2-tailed) & & .000 & .000 & .000 \\
& $\mathrm{~N}$ & 44 & 44 & 44 & 44 \\
$\mathrm{X}_{1}$ & Pearson Correlation & $.979^{* *}$ & 1 & $.960^{* *}$ & $-.958^{* *}$ \\
& Sig. (2-tailed) & .000 & & .000 & .000 \\
& $\mathrm{~N}$ & 44 & 44 & 44 & $-.968^{* *}$ \\
$\mathrm{X}_{2}$ & Pearson Correlation & $.950^{* *}$ & $.960^{* *}$ & 1 & .000 \\
& Sig. (2-tailed) & .000 & .000 & & 44 \\
& $\mathrm{~N}$ & 44 & 44 & 44 & 1 \\
$\mathrm{X}_{3}$ & Pearson Correlation & $-.947^{* *}$ & $-.958^{* *}$ & $-.968^{* *}$ & .000 \\
& Sig. (2-tailed) & .000 & .000 & 44 & 44 \\
\hline
\end{tabular}

**. Correlation is significant at 0.05 level (2-tailed).

Source: Primary data, 2014. 
The findings also reveal high positive correlation between university resource conditions $\left(\mathrm{X}_{2}\right)$ and linkage strategies $\left(\mathrm{X}_{1}\right)$. This was indicated by $\mathrm{r}=0.96>0.7$ and correlation being significant at $\mathrm{p}$ value $(0.000)<0.05$. When each of the indicators of university resource conditions were treated as independent variables and regressed with university performance, value (V) and dynamic capability (DC) were found the most significant predictors of university performance $\left(\mathrm{Y}_{2}\right)$ with both having $\mathrm{p}$ values $(0.01)<0.05$. Both rareness $(\mathrm{R})$ and individual and group behaviour (IGB) were found insignificant predictors of university performance since they both had $\mathrm{p}$ values less than 0.05 (0.081 and 0.061 respectively). Inimitability (IM), Non-substitutability (NS) and Resource Dependence Level (RDL) all had $\mathrm{p}$ values less than 0.05 thus are significant predictors of university performance.

From Table 3, the regression model relating each resource condition indicator and university performance can be expressed as $\mathrm{Y}_{2}=0.55+0.41 \mathrm{~V}+0.07 \mathrm{R}+0.31 \mathrm{IM}+0.16 \mathrm{NS}+0.32 \mathrm{RDL}+0.42 \mathrm{DC}+0.08 \mathrm{~GB}$. The model implies that a unit percentage increase in value would cause $0.41 \%$ increase in university performance $\left(\mathrm{Y}_{2}\right)$, a unit percentage increase in rareness would cause $0.07 \%$ increase in university performance $\left(\mathrm{Y}_{2}\right)$, a unit percentage increase in inimitability would cause $0.31 \%$ increase in university performance $\left(\mathrm{Y}_{2}\right)$, a unit percentage increase in non-substitutability would cause $0.16 \%$ increase in university performance $\left(\mathrm{Y}_{2}\right)$, a unit percentage increase in resource dependence level would cause $0.32 \%$ increase in university performance $\left(\mathrm{Y}_{2}\right)$, a unit percentage increase in dynamic capability would cause $0.42 \%$ increase in university performance $\left(\mathrm{Y}_{2}\right)$ and finally a unit percentage increase in individual and group behaviour would cause $0.08 \%$ increase in university performance $\left(\mathrm{Y}_{2}\right)$.

Table 4. Regression and ANOVA on resource conditions-performance

\begin{tabular}{|c|c|c|c|c|c|c|c|c|c|c|}
\hline \multirow[b]{3}{*}{ Regression } & \multicolumn{5}{|c|}{ Standardised } & \multicolumn{3}{|c|}{ df } & \multicolumn{2}{|c|}{ Collinearity Statistics } \\
\hline & \multicolumn{2}{|c|}{ Coefficients } & \multirow[t]{2}{*}{ Sig. } & \multirow{2}{*}{$\begin{array}{l}\mathrm{R} \\
.949^{\mathrm{a}}\end{array}$} & \multirow{2}{*}{$\begin{array}{l}\text { R Square } \\
.901\end{array}$} & \multirow{2}{*}{$\begin{array}{l}\mathrm{F} \\
46.905\end{array}$} & \multirow[b]{2}{*}{7} & \multirow{2}{*}{$\begin{array}{l}\text { Sig. } \\
.000^{\mathrm{a}}\end{array}$} & & \\
\hline & $\mathrm{B}$ & Std. Error & & & & & & & Tolerance & VIF \\
\hline Constant & .55 & .209 & .000 & & & Residual & 36 & & & \\
\hline Value & .41 & .225 & .010 & & & & & & .341 & 2.981 \\
\hline Rareness & .07 & .356 & .081 & & & & & & .112 & 9.185 \\
\hline Inimitability & .31 & .291 & .020 & & & & & & .813 & 5.798 \\
\hline Non-substitutability & .16 & .136 & .042 & & & & & & .021 & 11.86 \\
\hline $\begin{array}{l}\text { Resource } \\
\text { Dependence Level }\end{array}$ & .32 & .276 & .022 & & & & & & .341 & 4.974 \\
\hline Dynamic Capability & .42 & .292 & .010 & & & & & & .213 & 5.383 \\
\hline
\end{tabular}

Regression model is significant at the 0.05 level (2-tailed).

Source: Primary data, 2014.

Table 4 shows that $\mathrm{F}(7,36)=46.905$, p value $(0.000)<0.05$, tolerance values $>0$ and all VIF values $<10$ (apart from non-substitutability with VIF (11.86)>10). Thus the regression model relating university resource conditions and university performance is a valid relationship. The square of multiple correlations $\left(\mathrm{R}^{2}\right)=0.901$ shows that resource conditions explain $90.1 \%$ of variation when other variables in the conceptual model (Fig. 1.1) are constant. Consequently the second hypothesis was accepted as follows: Hypothesis 2: There is a significant relationship between resource conditions and university performance.

To test hypothesis 3 , that there is a moderating effect of resource conditions on the relationship between linkage strategies and organizational performance, a hierarchical multiple regression analysis was conducted. In the first step, two variables were included: linkage strategies $\left(\mathrm{X}_{1}\right)$ and university resource conditions $\left(\mathrm{X}_{2}\right)$. An interaction term $\left(\mathrm{X}_{1} * \mathrm{X}_{2}\right)$ was also created and two regression models were run. Model a without the interaction term and model $\mathrm{b}$ with the interaction term to find out if the models are significant and if the amount of variance accounted for in Model $\mathrm{b}$ (with the interaction term) is significantly more than Model a (without the interaction term). Moderating effects were tested by observing if the change in the squared multiple correlation coefficient $\left(\Delta \mathrm{R}^{2}\right)$ and $\mathrm{F}$ ratio given by the interaction is significantly greater than zero. 
Table 5. ANOVA Test on uncentered model 2 terms

\begin{tabular}{|c|c|c|c|c|c|c|}
\hline Model & & Sum of Squares & df & Mean Square & $\mathrm{F}$ & Sig. \\
\hline \multirow[t]{3}{*}{$\mathrm{a}$} & Regression & 45.786 & 2 & 22.893 & 131.760 & $.000^{\mathrm{a}}$ \\
\hline & Residual & 7.124 & 41 & .174 & & \\
\hline & Total & 52.909 & 43 & & & \\
\hline \multirow[t]{3}{*}{$\mathrm{b}$} & Regression & 47.858 & 3 & 15.953 & 126.325 & $.000^{\mathrm{b}}$ \\
\hline & Residual & 5.051 & 40 & .126 & & \\
\hline & Total & 52.909 & 43 & & & \\
\hline
\end{tabular}

Regression model is significant at the 0.05 level (2-tailed).

Source: Primary data, 2014.

As shown in Table 5, model (a) is significant with ANOVA test showing that $F(2,41)=131.760, p<0.05$. Model $\mathrm{b}$ is also significant with ANOVA test showing that $\mathrm{F}(3,40)=126.325, \mathrm{p}<0.05$. Model (b) with the interaction between linkage strategies and university resource conditions accounted for significantly more variance than just linkage strategies $\left(\mathrm{X}_{1}\right)$ and university resource conditions $\left(\mathrm{X}_{2}\right)$ by themselves. The change in squared multiple correlation coefficient $\left(\Delta \mathrm{R}^{2}\right)=0.039$, which is significantly greater than zero, $p<0.05$, implying that resource conditions explain additional $3.9 \%$ variation in university performance. F-Change, F $(1,40)=16.410$ shows a significant variation in the model fit with $\mathrm{p}<0.05$. This indicates that there is potentially significant moderating effect of university resource conditions on the relationship between linkage strategies and university performance.

Table 6. Model Summary on Uncentered model 2 terms

\begin{tabular}{lllllllllll}
\hline \multicolumn{1}{c}{ Change Statistics } \\
Model & $\mathrm{R}$ & R Square & Square & Estimate & Change & F Change & df1 & df2 & Sig. F Change \\
\hline $\mathrm{a}$ & $.930^{\mathrm{a}}$ & .865 & .859 & .41683 & .865 & 131.760 & 2 & 41 & .000 \\
$\mathrm{~b}$ & $.951^{\mathrm{b}}$ & .905 & .897 & .35536 & .039 & 16.410 & 1 & 40 & .000 \\
\hline
\end{tabular}

Regression model is significant at the 0.05 level (2-tailed).

Source: Primary data, 2014.

To avoid potentially problematic high multicollinearity with the interaction term, the independent and moderating variables have to be centered (Aiken and West, 1991). Linkage strategies and university resource conditions were therefore centered and a new interaction term between them created and then added to the regression model. This accounted for a significant proportion of the variance in university performance caused by moderating effect of university resource conditions. As shown in Table 3.6, the change in squared multiple correlation coefficient $\left(\Delta \mathrm{R}^{2}\right)=0.039$ and it is significantly greater than zero with $\mathrm{p}<0.05$. This shows that university resource conditions explain additional $3.9 \%$ variation in university performance. Further, $\Delta \mathrm{F}(1,40)=$ $16.410, \mathrm{p}<0.05$ shows significant variation in the model fit. Since $t$ values (5.688 and 4.051) are significantly greater than zero, the values of standardised coefficient, Beta (1.320 and 0.245) of model 2 are significantly different from zero showing that resource conditions is significantly associated with university performance.

Hypothesis 3 was therefore accepted that there is significant moderating effect of university resource conditions on the relationship between linkage strategies and university performance.

\section{Discussion}

The findings of this study reaffirms that strategies fused with linkage components enhance organisational performance. Therefore, when organisational strategies do not reflect linkage aspects in reference to the industry it serves, performance declines. The test results on the first hypothesis shows that there exists a significant relationship between linkage strategies and organisational performance. This confirms that performance of a firm 
can only be accurately measured in terms of its linkage with the economic sector that it serves and not in isolation, such that the more linkage aspects are fused in the strategies the better the performance of a university. Secondly the results show that strength of the relationship between Linkage strategies and university performance depends upon university resource conditions such that linkage strategies are strongest when university resource conditions are high and weakest when university resource conditions are low. The study further demonstrates that, in addition to a moderating role, there also exists direct relationship between resource conditions and university performance. From the foregoing, universities need to develop policy framework that incorporates linkage aspects during strategy formulation and consider the influence of resource conditions in order to realise superior performance and remain relevant. Otherwise, without coherent linkage strategies for developing skilled manpower, taking resource conditions in consideration, it remains unclear how Africa will realise Sustainable Development Goals (SDGs). The study findings have theoretical, practical and policy implications for future researchers, university authorities and all stakeholders. Resource-based view (RBV) as the main theory anchoring the study provides a favourable model for analysing the appropriate strategies that can provide effective university education-industry linkages. The regression model linking strategies and university performance demonstrates that higher learning institutions authorities can apply the model in predicting performance of their institutions. RBV provides the frame work within which the linkage strategies can be identified from the internal firm resources. It is clear from the findings that industry linkage components must be fussed in the strategies in order to realise superior organisational performance. For practice, the study highlights the most significant components of strategy that impacts on university performance. Curriculum orientation, industrial attachment, teaching and learning focus and collaborative research have been established as significant predictors of university performance. The university authorities must therefore strategically link these indicators to the industry by involving stakeholders in strategy formulation and implementation process, in order to realise superior performance. Findings show that the university authorities can improve their performance by identifying and improving the condition of institutional resources in order to realise superior performance. Inimitability was found the most significant indicator of resource conditions while value and dynamic capability were the most significant predictors of performance. The implication is that universities should focus on strategies that make their resources inimitable in order to realize superior performance. University resource conditions have significant moderating effect on the relationship between linkage strategies and university performance. Universities need to set policies that have advantage-creating resource conditions. Future research could focus on studying organisations under a relatively stable environment. This study and empirical findings from other studies indicate that resource conditions are the most critical determinant of organisational performance in a state of influx. It would be interesting to test these convergent findings in a relatively stable environment. Future studies should be undertaken in Kenya and the East African region using relevant data from a variety of media sources and for longer periods of time.

\section{Acknowledgments}

Completing this study was through the support of many individuals and institutions. We would like to sincerely thank all the university authorities who allowed us to collect data from their institutions. The findings would not have been credible without participation of each and every university that took part in one way or another. Many universities gave a lot of insights that enabled us pre-test questionnaire and improve it further. Finally this study would not have been successful without the involvement of experts, senior researchers and professionals who contributed immensely to questionnaire construction process. It could not be possible to mention every person who assisted us in one way or another but to all, we say thank you and may God bless you.

\section{References}

Aguillo, I. F., Granadino, B., Ortega, J. L., \& Prieto, J. A. (2006). Scientific Research Activity and Communication Measured with Cybermetric Indicators. Journal of the American Society for the Information Science and Technology, 57, 1296-1302. https://doi.org/10.1002/asi.20433

Aiken, L. S., \& West, S. G. (1991). Multiple regression: Testing and interpreting interactions. Thousand Oaks. CA. Sage.

Barney, J. B. (1991). Firm Resources and Sustained Competitive Advantage. Journal of Management, 17, 99-120. https://doi.org/10.1177/014920639101700108

Bryman, A., \& Bell, E. (2007). Business Research Methods. Oxford University Press. New York.

Carter, S. M., \& Ruefli, T. W. (2006). Intra-Industry Reputation Dynamics under a Resource-Based Framework: Assessing the Durability Factor. Corporate Reputation Review, 9, 3-25. https://doi.org/10.1057/palgrave.crr.1550006 
Chatterton, P., \& Goddard, J. B. (2001). The Response of universities to Regional Needs. European Journal of Education, Research, Development and Policies, 35, 460-475.

Collis, D. J., \& Montgomery, C. A. (1995). Competing on resources: Strategy in the 1990s. Harvard Business School Review, 118-128.

Commission for University Education. (2013). Status of Universities Operating in Kenya. Retrieved from http://www.che.or.ke/contactus.html

Dess, G., Newsport, S., \& Rasheed, A. M. (1993). Configuration Research in Strategic Management: Key Issues and Suggestions. Journal of Management, 19, 775-795. https://doi.org/10.1177/014920639301900403

Dillman, D. (2000). Mail and Internet Survey-The Tailored Design Method. New York. John Wiley and Sons, Inc.

Eshiwani, G. S. (1999). Education in Kenya since Independence. Nairobi. East African Educational Publishers.

Ginies, P., \& Mazurelle, J. (2010). Managing university-industry relations: A study of institutional practices from 12 different countries. Journal of Higher Education, 5, 7-10.

Grant, R. (2010). Contemporary Strategy Analysis: Text \& Cases (7th ed.). Chichester: John Wiley\& Sons.

Grant, R. (1991). A Resource-Based Perspective of Competitive Advantage. California Management Review, 33, 114-135. https://doi.org/10.2307/41166664

Herman, R. D., \& Renz, D. O. (1998). Non-profit Organisational Effectiveness: Contrasts between especially effective and less effective organisations. Non-profit Management and Leadership Journal, 23-38. https://doi.org/10.1002/nml.9102

Irungu, S. M. (2007). The Effect of Top Management Teams on the Performance of Publicly Quoted Companies in Kenya. Unpublished PhD Thesis, School of Business, University of Nairobi, Kenya.

Justus, M., Kibera, F., \& Ogutu, M. (2011). Extent to which University- Industry Linkage Exists inKenya: A Study of Medium and Large Manufacturing Firms in Selected Industries in Kenya Prime. Journal for Business Administration and Management (BAM), 4, 163-169.

Kaplan, R. S., \& Norton, D. P. (2008). The Balanced Score Card. Harvard Business School press. Boston. MA.

Karanja, F. N. (2011). Mending the Bridge between Higher Institutions of Learning and Industry, a Case Study of School of Engineering, University of Nairobi. Journal of Management, 190-199.

Kline, P. (1999). The Handbook of Psychological Testing. London. Routledge.

Kothari, C. R. (2004). Research Methodology: Methods and Techniques (2nd ed.). New Age International Limited. New Delhi.

Nachmias, C. F., \& Nachmias, D. (2004). Research Methods in the Social Sciences (5th ed.). Arnold. Landon.

Prescott, J. E. (1986). Environments as Moderators of the Relationship between Strategy and Performance. The Academy of Management, 29, 329-346. https://doi.org/10.2307/256191

Spyros, K., \& Vicki, C. (2009). What Are the Long-Term Effects of Small Class Sizes on the Achievement Gap? Evidence from the Lasting Benefits Study. American Journal of Education, 116, 125-154. https://doi.org/10.1086/605103

Wernerfelt, B. (1984). A Resource Based View of the Firm. Strategic Management Journal, 5, 171-80. https://doi.org/10.1002/smj.4250050207

Wernerfelt, B. (1995). A Resource Based View of the Firm: Ten Years after. Strategic Management Journal, 16, 171-174. https://doi.org/10.1002/smj.4250160303

\section{Copyrights}

Copyright for this article is retained by the author(s), with first publication rights granted to the journal.

This is an open-access article distributed under the terms and conditions of the Creative Commons Attribution license (http://creativecommons.org/licenses/by/4.0/). 